\title{
The Impact of 16th Century German Botanical Treatises on Garcia de Orta's Coloquios dos Simples
}

\author{
João Paulo S. Cabral \\ Faculdade de Ciências, Universidade do Porto, Porto, Portugal \\ Email: jpcabral@fc.up.pt,jpscabral@hotmail.com
}

How to cite this paper: Cabral, J. P. S. (2020). The Impact of 16th Century German Botanical Treatises on Garcia de Orta's Coloquios dos Simples. Advances in Historical Studies, 9, 20-37.

https://doi.org/10.4236/ahs.2020.92003

Received: April 2, 2020

Accepted: May 31, 2020

Published: June 3, 2020

Copyright $\odot 2020$ by author(s) and Scientific Research Publishing Inc. This work is licensed under the Creative Commons Attribution International License (CC BY 4.0).

http://creativecommons.org/licenses/by/4.0/

\begin{abstract}
In the early sixteenth century, Italian, French, Portuguese, Spanish, Flemish and German academics led the revival of the study of botany. In Germany, Otho Brunfels, Jerome Bock, Leonhart Fuchs, Adam Lonicerus, and Valerius Cordus published herbals dealing with European medicinal plants, but notes on Asian products remain invaluable. The Portuguese doctor Garcia de Orta sailed to Goa in 1534. There, he published his Coloquios dos Simples e Drogas da India in 1563. It is precisely in the context of Indian materia medica that Garcia de Orta's path intersects with that of the German academics. The aim of this paper is to analyze the influence of Valerius Cordus' and Leonhart Fuchs' works on Orta's Coloquios. To this end, the original Latin descriptions of Asian medicinal products made by Cordus and Fuchs were compared with Orta's interpretations. It was observed that Garcia de Orta makes good use of Cordus's descriptions of cardamom, cassia lignea, cinnamon, lignum aloes (agarwood) and tamarind fruits. His attitude towards Fuchs, however, was less accommodating because he was, in Orta's words, "a heretic condemned for being a Lutheran" and he distorted the words of the German master about ivory. It was concluded that neither Garcia de Orta's Renaissance humanism nor his scientific view of Indian natural history was any match for the influence of his religious beliefs. Orta did not escape the profound doctrinal and theological division that was raging Europe after the emergence of the Reformation movement.
\end{abstract}

\section{Keywords}

Botany, Garcia de Orta, Valerius Cordus, Leonhart Fuchs, German Botanists

\section{Introduction}

In the sixteenth century, there was a revival of botany from medieval times. In ad- 
dition to the plants already described by masters in Antiquity such as Theophrastus, Dioscorides and Pliny, many European plants and some previously little known oriental plants were added (Pires, 1984; Egerton, 2003; Ogilvie, 2003). Italian ${ }^{1}$, French $^{2}$, Portuguese ${ }^{3}$, Spanish $^{4}$, Flemish $^{5}$ and German academics led the revival of botanical studies. In Germany, Otho Brunfels (ca. 1489-1534), Hieronymus Bock (1498-1554, also known as Hieronymus Tragus), Leonhart Fuchs (1501-1566), Adam Lonicerus (1501-1566) and Valerius Cordus (1515-1544), develop studies and practices in medicine, pharmacy, and botany in private, municipal, institutional or university domains, particularly in Wittenberg ${ }^{6}$ and Tübingen ${ }^{7}$. Following various paths, several of these German academics adhered to Protestantism, in particular Brunfels ${ }^{8}$, Bock $^{9}$, and Fuchs ${ }^{10}$ and this attitude, ${ }^{1}$ Particularly Luca Ghini (1490-1556) author of one of the first herbaria and founder of botanical gardens at Pisa and Florence, Antonio Musa Brasavola (1500-1555) author of Examen omnium simplicium medicamentorum quorum in officinis usus est published in 1536 and Pietro Andrea Mattioli (1501-1577) author of an Italian translation of Dioscorides's De materia medica (Egerton, 2003; Touwaide, 2003, 2008).

${ }^{2}$ Especially Jean Ruel (1474-1537) who translated Dioscorides's De materia medica from Greek into Latin and printed as early as 1516 and published in 1536 De natura stirpium libri tres (Egerton, 2003; Touwaide, 2003).

${ }^{3}$ Amatus Lusitanus (João Rodrigues de Castelo Branco, 1511-1568) who published a version of Dioscorides's De materia medica in Antwerp in 1536 (the first two books) and in Venice in 1553, and the description and treatment of 700 medical cases in Curationum Medicinalium published in Venice in 1566 (Friedenwald, 1937; Dias, 1964).

${ }^{4}$ Notably Andrés Laguna de Segovia (1499-1559) who published a translation into Spanish of Dioscorides's De materia medica in 1555.

${ }^{5}$ Singularly Rembert Dodoens (1517-1585) physician and botanist, author of several works dedicated to the study of plants, namely Herbarium (1533), Den Nieuwen Herbarius (1543), De frugum historia (1552), Des Cruydboeks (1554, in Dutch and Latin), Historia frumentorum (1566), Florum et coronariorum odoratumque historia (1574), Purgantium aliarumque eo facientium (1574), Historia vitis vinique (1574) and Stirpium historiae pemptades sex (1583) (Touwaide, 2003).

${ }^{6}$ Valerius Cordus studied and then taught at Wittenberg University. It should be noted that it was from this university, founded in 1502, that the Reformation movement was set in motion (Husemann, 1876; Stauffer, 1970: p. 15; Schmitz, 1981).

${ }^{7}$ In 1534, Ulrich, Duke of Württemberg, definitely links Tübingen University to the Reform, using the intervention of Ambrosius Blarer (Ambrose Blarer of Giersberg, 1492-1564) who reorganizes his curricula between 1534 and 1537, a task later pursued by Johann Brenz (1499-1570). The residence associated with the university was transformed into a protestant seminary. New teachers were hired, including Leonhart Fuchs, professor of medicine and botany (Feger, 1955; Brendle, 2001).

${ }^{8}$ Otho Brunfels was a monk in the Carthusian monastery of Mainz and then in Königshofen, but in 1521, influenced by Ulrich von Hutten (1488-1523), he abandoned the Catholic faith to become a Lutheran preacher first in Steinau an der Strasse (1521-1522) and then in Neuenburg am Rhein (1522-1524). He published a volume of sermons by pre-Reformation reformer John Huss. However, he disagreed with Luther and Ulrich Zwingli. In 1524 he returned to Strasbourg where he dedicated himself to medicine. Later, he lived in Basel, acting as municipal doctor (Grimm, 1955; Stannard, 1970b). ${ }^{9}$ Hieronymus Bock studied in Heidelberg and in 1533 attended the Benedictine monastery of San Fabian, near Hornbach. He had abandoned the Catholic faith and adhered to Protestantism and establishes himself in Zweibrücken by 1523. He assumed the duties of teacher by appointment of Count Ludwig, who employed him to run the gardens and serve as an apothecary (Engler, 1875; Stannard, 1970a; Egerton, 2003).

${ }^{10}$ When studying in Ingolstadt University, Leonhart Fuchs became acquainted with Philip Melanchthon (1497-1560). He was later invited by the Margraviate of Brandenburg to found a Protestant university in Ansbach, a project that in the event did not materialize. Invited by Ulrich, Duke of Württemberg (possibly influenced by Melanchthon) to reform Tübingen University according to the principles of Reform, Fuchs took office in August 1535. He maintained contact with the reformer of Tübingen University, Johann Brenz (Rath, 1961). 
especially of those who abandon the Catholic faith to embrace another creed, would be scrutinized by the Portuguese Inquisition ${ }^{11}$ resulting in many of their works being listed in the Index ${ }^{12}$, apart from those strictly related to botany and medical matters.

Concerning herbals ${ }^{13}$, these academics reprinted Dioscorides's treatise De materia medica ${ }^{14}$, to which they added comments and observations ${ }^{15}$, as well as corrections $^{16}$, but they also wrote new works (Elliott, 2011), in which they incorporated the knowledge then available on medicinal plants, with emphasis on those of central and northern Europe, which the treatises by the masters of Antiquity did not have (Pires, 1984; Ogilvie, 2003; Touwaide, 2003; Cohen, 2010). These works are generally illustrated with woodcuts, which were intended to represent the plants described in the text ${ }^{17}$. The realism of the drawings is re-

\footnotetext{
${ }^{11}$ The Inquisition was a special court created by Pope Gregory IX (1227-1241) in various European countries to combat all forms of religious heresy or discrepancy, witchcraft and sexual aberrations. Practices allowed physical or moral torture during the investigation, and punishments that could be as severe as death by fire. The inquisitorial process accepted anonymous denunciations and concealed the names of the witnesses. Once arrested, the defendant's property was confiscated and their house sealed. The lawyer was at the court's own service and knew only the libels and sentences communicated to the defendant. There was no right of appeal against the final sentence. The purpose was to get the accused to confess and repent, but when this was not obtained, the court handed the defendant over to the civil powers that pronounced and executed the death sentence. As a result of a long stay of Muslims and Jews, the Inquisition found favorable ground for its action in the Iberian Peninsula, especially during the 16th and 17th centuries. It dedicated itself primarily to the persecution of the Jews and, to a lesser extent, the Lutheran Protestants (Saraiva, 1969; Bethencourt, 1994).

${ }^{12}$ After the Council of Trent, Pope Pius IV created the "Index of Forbidden Books" and determined that all works related to faith and customs should be subjected to prior examination. In some cases printing was allowed, but with parts of the text removed. The surveillance of public and private libraries, visits to ships and the control of seaport entrances was also instituted. Works of a purely scientific, literary or philosophical nature were generally excluded from prohibitions, provided that they did not conflict with Tridentine recommendations. Love poetry, theater, sentimental literature, and other texts that questioned the current status quo or used languages less in line with current practice were the hardest hit. Manifestations of popular culture, often tending toward a certain heterodoxy, and all forms of approach to any form of evangelism or positions close to Protestantism, were the main targets. In Portugal, the Roman Indices were in force, to which were added indices of Portuguese works with a set of its own rules applicable in the country. The Portuguese printed list of forbidden books was published in 1551, 1561, 1564, and in 1581 ("Catalogo dos livros que se prohibem", "Catalog of forbidden books"). Censorship of the press was an important repressive instrument used by the Inquisition in Portugal, and it had an influence on Portuguese culture and mentality that was indisputably and indelibly negative (Winius, 1998; Cadafaz de Matos, 2001).

${ }^{13}$ Treatises on medicinal plants with descriptions of the plants' morphology and their medicinal importance and use, intended to enable doctors and apothecaries to know which plants to use for medical purposes and how to identify them in the field (Singer, 1927; Stannard, 1969; Elliott, 2011).

${ }^{14}$ The first translations of Dioscorides's De materia medica into vernacular languages were done by Mattioli in 1544 into Italian, and by Andrés Laguna in 1555 into Spanish (Touwaide, 2003, 2008; Elliott, 2011).

${ }^{15}$ The following editions can be mentioned: Otho Brunfels, In Dioscoridis historiam plantarum certissima adaptatio (1543); Valerius Cordus, Annotationes in Dioscorides de materia medica libros, with posthumous editions in 1549 and 1561.

${ }^{16}$ One of the first works to point out errors in the treatises of the masters of Antiquity was Niccolò Leoniceno (1428-1524) in Plinii ac plurium aliorum auctorum qui de simplicibus medicaminibus scripserunt errores notati published in 1492, in which he explained 22 errors by Pliny due to his mistranslation or misunderstanding and 17 errors by Arabic authors and their Latin commentators (Egerton, 2003).

${ }^{17}$ The following works deserve special mention: Otho Brunfels's Herbarum vivae icones (1530, 1531 and 1536), Hieronymus Bock's new Kraüterbuch (1539), Leonhart Fuchs's De historia stirpium commentarii insignes (1542), and Adam Lonicerus's Kreuterbuch (1557) (Touwaide, 2008; Elliott, 2011).
} 
markable and many plant drawings depict their flower and fruit. We know that many drawings were made by direct observation. In some editions, the drawings were colourful, constituting exceptional works in both the scientific and bibliophile fields. Imbued with the Renaissance spirit, we note the desire to better describe the plants and their properties, adding, or even correcting, the knowledge of the writers from Antiquity. In some of these herbals, the plants are no longer organized in alphabetical order but rather grouped into large groups: wild and cultivated, trees, shrubs and herbs (herbaceous). In these works, we can find the description of many European plants and products, but notes on Asian substances remain invaluable. It is true that aloe ${ }^{18}$, asafetida ${ }^{19}$, hemp $^{20}$, flax $^{21}$, oriental sweetgum $^{22}$, jujube ${ }^{23}$, cinnamon, costus ${ }^{24}$, datura ${ }^{25}$, banana, areca nut ${ }^{26}$, ginger ${ }^{27}$, opium $^{28}$, peppers ${ }^{29}$, camel grass ${ }^{30}$, incense ${ }^{31}$, and myrrh $^{32}$ among others had already been described in the works of Theophrastus, Dioscorides, and Pliny, but the German masters wanted to improve and extend the knowledge of these products and plants.

Born in Castelo de Vide (Portugal) in the early 16th century, Garcia de Orta, son of Castilian Jews, completed his academic training in Salamanca and Alcalá de Henares (Spain). His approach to Martim Afonso de Sousa (1490/15001564), future governor of the Portuguese State of India, would be decisive for the young doctor's future in that he set sail for Goa in 1534, and did not return to Portugal. Garcia de Orta would accompany his patron on several military expeditions, in both the north and south of the Indian subcontinent, and had the opportunity to see the rich and novel Indian natural history with his own eyes. His contact with the local elites allowed him to acquire knowledge about the Indian fauna, flora and materia medica. All this wealth of knowledge would be incorporated in the only work that has come to us-his Coloquios dos Simples e das Drogas da India, published in Goa in 1563. Garcia de Orta died in 1568. On October 28 of that year, his sister, Catarina Orta, was arrested by the Inquisition. She would be burned at the stake. Garcia de Orta was posthumously convicted of Judaism. His bones were exhumed and burned along with an effigy in an auto-da-fé in 1580 (Ficalho, 1886; D’Esaguy, 1937; Friedenwald, 1941; Dias, 1964;

\footnotetext{
${ }^{18}$ Aloe spp., in particular Aloe perryi Baker from Socotorá island.

${ }^{19}$ The dried latex exuded from the rhizome of Ferula alliacea Boiss. and Ferula assa-foetida L.

${ }^{20}$ The leaves of Cannabis sativa L.

${ }^{21}$ Linum usitatissimum L.

${ }^{22}$ The sap of Liquidambar orientalis Mill.

${ }^{23}$ The fruit of Ziziphus jujuba Mill.

${ }^{24}$ The root of Saussurea costus (Falc.) Lipsch.

${ }^{25}$ Datura stramonium L., Datura fastuosa L. and Datura alba Nees von Es.

${ }^{26}$ The fruit of Areca catechu L.

${ }^{27}$ The rhizome of Zingiber officinale Roscoe.

${ }^{28}$ The milky juice of the capsules of Papaver somniferum $\mathrm{L}$.

${ }^{29}$ The fruit of Piper nigrum L., Piper officinale DC, Piper longum L. and Piper trioicum Roxb.

${ }^{30}$ The leaves of Cymbopogon schoenanthus (L.) Spreng.

${ }^{31}$ The resin extracted from several Boswellia species, namely B. sacra Flückiger, Boswellia papyrifera (Del.) Hochst, B. carteri Birdwood and B. frereana Birdwood.

${ }^{32}$ The resin extracted from several Commiphora species, namely $C$. myrrha (Nees) Engl. in DC, $C$. erythraea (Ehrenb.) Engl. in DC and C. madagascariensis Jacq.
} 
Kapil \& Bhatnagar, 1976; D’Cruz, 1991; Mathew, 1997; Pearson, 2001; Cohen, 2010; Pimentel \& Soler, 2014; Paiva, 2018).

Garcia de Orta was in a privileged position over European naturalists because he could see with his own eyes and study the Indian plants, animals, and minerals that had been coming to Europe for centuries, and others that were almost or totally unknown to Europeans. The bibliography quoted in the Coloquios, and surely read by Garcia de Orta, is vast ${ }^{33}$; it spans every botanical luminary, from the masters of Antiquity to his contemporaries, including the German naturalists. He wanted to rewrite Indian natural history and materia medica, and explain everything written about it (Friedenwald, 1941; Kapil \& Bhatnagar, 1976; Grove, 1996; Mathew, 1997; Pimentel \& Soler, 2014; Cabral, 2015; Paiva, 2018).

Valerius Cordus and Leonhart Fuchs are the 16th-century German academics most cited by Garcia de Orta. What was the influence of the works of these masters on Orta's Coloquios? To what extent did Orta's religious beliefs influence his evaluation of Cordus and Fuchs' works? In order to answer these questions, we searched in Coloquios for mentions of the works of these two German masters and compared the original Latin descriptions of medicinal products with Orta's interpretations.

\section{The Impact of Valerius Cordus's and Leonhart Fuchs's Herbals on Garcia de Orta's Coloquios dos Simples}

The works of Valerius Cordus and Leonhart Fuchs were analyzed in several of Garcia de Orta's Coloquios. Valerius Cordus is mentioned in Colloquium 13, in relation to cardamom ${ }^{34}$. This species had already been mentioned by Dioscorides in his work De materia medica ${ }^{35}$ but he had not described the plant product itself (fruit and seed), mentioning only that the plant grew in India and Arabia, and indicating its therapeutic properties. Laguna (1555: p. 15) added more information to the original text, but he had not described the seeds either. Now, Garcia de Orta ${ }^{36}$ called upon Valerius Cordus because the German botanist had mentioned that the "major cardamom is almost like the acorn and the minor (cardamom) almost like hazelnut, and none of these is larger than a shelled pine

\footnotetext{
${ }^{33}$ Garcia de Orta quotes doctors (Galen, Celsus, Hippocrates), philosophers (Aristotle, Plato), and botanists (Theophrastus, Dioscorides and Pliny) of Antiquity, Muslim intellectuals (Serapion, Avicenna, Averroes, Rhazes), Middle Age intellectuals (Matteo Plateario, Matthaeus Silvaticus, Gerard of Cremona), his contemporaries (Antonio Musa Brasavola, Jean Ruel, Valerius Cordus, Andrés de Laguna, Nicolás Bautista Monardes, Amatus Lusitanus, Fuchs, Matthiolo).

${ }^{34}$ These names cover the fruits of two varieties of Elettaria cardamomum (L.) Maton, varieties that were correctly distinguished by Garcia de Orta. The smallest and most typical (and most aromatic) form existed in Malabar, and the largest (and least aromatic) form in Ceylon. The seed was used as a spice in the East to promote digestion and fortify the stomach (Gelásio Dalgado, 1894: p. 7, 1898: p. 188; Ricardo Jorge, 1962: pp. 234-237; Rodolfo Dalgado, 1982: p. 215; Schütz, 2009).

${ }^{35}$ Chapter 1.6.1.1 - 1.6.1.13 in Wellmann's Greek edition reproduced and studied in Alía Alberca (2010: pp. 40-41).

${ }^{36}$ All the transcripts of the Orta Coloquios dos Simples were translated by the author of the present work from the original Goa edition (Orta, 1563) using the specimen from the Portuguese National Library, res-456-p, currently available at http://purl.pt/22937. References to the edition by the Conde de Ficalho (Orta, 1891, 1895) are also presented.
} 
nut" ${ }^{37}$ and added that the "grains [seeds] are in the other large heads [fruits]"38. Indeed Cordus (1549: p. 9) had presented drawings of fruits of the cardamom showing the seeds inside and said that those of the major cardamom were larger than those of the minor cardamom, and different from the grain of Paradise ${ }^{39}$, the seeds of another medicinal plant ${ }^{40}$ also commonly used.

Valerius Cordus is again mentioned by Garcia de Orta in Colloquium 15 on cassia and cinnamon. For Garcia de Orta, V. Cordus had stated that "we lack the

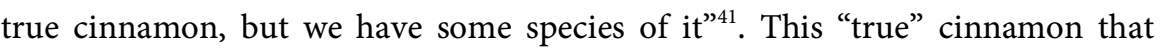
could no longer be obtained was what V. Cordus had considered to be the best

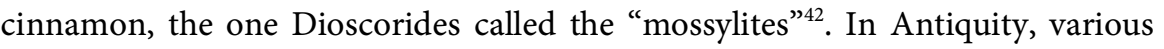
types of cinnamons, obtained from the bark of cassia lignea (Cinnamomum cassia (L.) J.Presl., mainly from India) or from others cinnamons (others species of the same genus Cinnamomum Schaeff., specially $C$. verum J.Presl., mainly from Ceylon), were brought from East to the West, in particular, to ancient Rome ${ }^{43}$. Cinnamon, or rather, cinnamons, the most expensive spices of high repute in Antiquity, were well known to the elite society in the West, but they were ignorant of the trees from which were obtained. However, some information came to the West because the ancient Greek and Roman authors-Theophrastus, Dioscorides, and Pliny - had pointed out that there were various types of cassias and

37 “Que ho mayor he quasi como bollota, e ho menor quasi como auelãa, e destes nenhum dos grandes he mayor que hum pinham com casca" (Orta, 1563: p. 47 recto; Orta, 1891: p. 176).

38“E diz q[ue] estes grãos estão metidos nas outras cabeças grandes” (Orta, 1563: p. 47 recto; Orta, 1891: p. 177).

39“ Cardamomum minus, nomen seruat in Pharmacopoliis, Germanice Cardamomie, Arabice Helbane. Maius uero, Arabice Heyl, diuersum a granis paradisi, quae aliqui Cardamomum minus improprie uocant, minus forte precio et uiribus inteligentes: mole enim maiora sunt, aliqui maior Cardamomo substituunt." ("Minor cardamom (retains the name for the pharmacists) [it is called] in German Cardamomie and in Arabic Helbane. The larger [cardamom], however, in Arabic is called Heyl, being distinct from Paradise grains, which some improperly call minor cardamom (perhaps because they perceive it to be less in value and potentiality) and others to confuse it with major cardamom, because, in terms of volume, [its grains] are bigger") (Cordus, 1561: p. 2 recto).

${ }^{40}$ The same drawing of Cordus's work appears to depict the fruit of Amomum grana-paradisi L. (current name: Aframomum melegueta K.Schum). Produced off the coast of Guinea, mainly in the area called the Costa da Malagueta, in present-day Liberia, these fruits were brought by the Muslim caravan trade across Mali to the Mediterranean, and have been known in European markets since the 13th century (Ricardo Jorge, 1962: pp. 226-227; Thomaz, 1995: pp. 219-345, 300; Quattrocchi, 2016: pp. 107-108).

41 “Q[ue] careçemos do verdadeiro Cinamomo se não que temos algũas espeçias delle” (Orta, 1563: p. 59 verso; Orta, 1891: p. 209).

${ }^{42}$ Chapter 1.14.1.1 - 1.14.2.1 in Wellmann's Greek edition reproduced and studied in Alía Alberca (2010: pp. 60-61).

${ }^{43}$ During the period of the Roman Republic, cloths, precious stones, timber and spices, in particular cinnamon, brought from India by Arab traders were redistributed at Socotra Island and Cape Gaurdafui, and carried to the Nile and the Mediterranean, and then to Rome. Under Augustus, the establishment of peace and stable rule throughout the Mediterranean altered the situation. In $25 \mathrm{BC}, \mathrm{Au}-$ gustus sent an expedition led by Aelius Gallus into Arabia with orders to subdue the kingdoms which he found, which was achieved. By 21 BC the Ethiopians were under his control. In the meantime, the number of vessels leaving Egyptian ports markedly increase and, more importantly, Roman mariners discovered the use of the monsoon winds to reach India, giving a great boost to the Indian trade and leading to a general decrease in prices. The Arabs retained some of the trade of Indian products, notably of cinnamon and cassia, probably by arrangement with the Indian merchants (Schoff, 1912: p. 4; Thorley, 1969: p. 218). 
cinnamons and that they were obtained from different plants. However, it was thought that these were small shrubs less than one meter high. Now, Valerius Cordus took up some ideas of the ancient writers about cassia lignea and cinnamon. He stated that there are different species of cassia lignea and cinna$\operatorname{mon}^{44}$, that the plants were related to each other ${ }^{45}$, that cinnamon was the bark of these bushes and in German it was called "zimetrinden" ${ }^{\text {". }}$. However, as Garcia de Orta points out, V. Cordus states that the best types of cinnamon were no longer possible to obtain ${ }^{47}$.

In Colloquium 30 on lignum aloes (agarwood) ${ }^{48}$, Garcia de Orta call upon again to V. Cordus, who had pointed out, according to Orta, that "the meanest spice is from Rhodes" ${ }^{\text {"9 }}$. Indeed, from the words of the German master, we know that the wood of a tree growing on the island of Rhodes, related to the Ethiopian olive tree ${ }^{50}$, was sold in Europe as if it were lignum aloes ${ }^{51}$. The adulteration was justified by the lower price and better accessibility of this wood compared to the true Asian wood. V. Cordus goes further and even gives us a description of the genuine lignum aloes.

Tamarind fruit, or the Indian date, the fruit of Tamarindus indica L. had not

44"Cinnamomi non pauciores quam Casiae species sunt" ("There are no fewer species of cinnamon than cassia") (Cordus, 1549: p. 451).

45"Cum uero Casia et Cinnamomum plures habeant species, sintque inter se ualde cognatae arbusculae, temerarium esset pronunciare, nos Cinnamomo carere." "Since cassia and cinnamon have many species and the bushes are related to each other, it would be unwise to say that we lack cinnamon.") (Cordus, 1549: p. 451).

46" Cinnamomum autem, ut hodie affertur, est cortex tantum suae arbasculae, quam quidam Canellum uocant, nos uero zimetrinden." ("Cinnamom, as it is now consumed, is, however, only a bark of its bushes, so that certain men call it cinnamon, while we [call it] Zimetrinden.”) (Cordus, 1549: p. 451).

47" Tali autem hodie omnino caremus; et habemus tantum ex omnibus uix unam speciem, eam scilicet, quae Mosilicae Casiae similis est, quae item omnium max[ime] arborescit." ("At present, we do not currently have [one species] of this kind, and hardly among all species can we find even one, whatever, that is similar to the [species] Mosilica Cassia and which, above all, grows as a tree.") (Cordus, 1549: p. 451). The majority of $16^{\text {th }}$ century botanists, namely Valerius Cordus, Andrés Laguna and Garcia de Orta thought that cinnamon (Cinnamomum verum J.Presl. from Ceylon) did not reach Europe, an imprecision that was not made, for instance, by Amatus Lusitanus (Ricardo Jorge, 1962: pp. 239-241).

${ }^{48}$ The resin and fragrant wood of Aquilaria agallocha Roxb., an indigenous plant of the Himalayas and Assam, and of Aquilaria malaccensis Lam., indigenous of Malaca. The wood was used as incense and much appreciated in Europe (Gelásio Dalgado, 1894: p. 17; Ricardo Jorge, 1962: pp. 246-247; Rodolfo Dalgado, 1982: pp. 17, 521-522; Schütz, 2009).

49“'Diz que a speçia mais vil he baxa q[ue] ha ha A de rrodes" (Orta, 1563: p. 122 verso; Orta, 1895: p. $56)$.

${ }^{50}$ The African olive tree that grows spontaneously in Ethiopia is Olea europaea subsp. cuspidata (Wall. ex G.Don) Cif.). The hard, heavy and beautiful golden-brown wood is used for furniture, ornaments, spoons and durable fence posts. This plant does not grow spontaneously in the Mediterranean basin, where two other subspecies thrive: Olea europaea subsp. europaea (olive tree) and Olea europaea subsp. sylvestris (Mill.) Lehr. (wild olive tree).

51" Pro Agallocho plerique uendunt lignum Rhodium uel Rhodisium uulgo dictum: quod uilior Agallochi species est: cuius lignum est solidum, durum, uarii coloris, amarum: et uidetur Oleastri uel oleae Aethiopicae lignum esse." ("Most people sell Rhodian [Rhodes Island] wood, as the people say, instead of Agallocho, because this type of wood is cheaper than Agallocho (whose wood is dense, hard, of various colors, and rough), resembling the wood of a poor relative of the Ethiopian olive tree") (Cordus, 1561: p. 8 verso). 
been mentioned by Dioscorides. According to Garcia de Orta in Colloquium 52, V. Cordus had pointed out that the tamarind fruit was different from the "fenico balano" 52 . Dioscorides had applied the designation of "fenico balano" to mature dates, purple in color ${ }^{53}$, which are essentially different from the tamarind fruit ${ }^{54}$. Not being the tamarind fruits originally described by Dioscorides, 16th century versions of this treatise added new information about this medicinal fruit. Cordus (1549), published before Laguna (1555) and the Garcia de Orta's Coloquios dos Simples (1563), brought to Europe important news about these tropical fruits, which, despite their name, were morphologically distinct from dates. V. Cordus correctly states ${ }^{55}$ that the tamarinds were different from the dates and were long, finger-shaped and had an acidic taste. They were the "wild dates of India”.

Leonhart Fuchs is also mentioned by Garcia de Orta in his Coloquios. The first reference we find is in Colloquium 50 dedicated to the spikenard (Nardostachys jatamansi (D. Don) DC.), a plant with a native range from Himalaya to Central China ${ }^{56}$, whose rhizome was used as a medicine from ancient times (Ricardo Jorge, 1962: p. 253; Schütz, 2009). Dioscorides had designated this plant as "Nardus spica", by virtue of the morphology of the rhizome (which he calls a root because it is underground) which, in the type called "Syriac", was "very hairy, red, smelling" and in the type "Gangitis" (from the nearby Ganges river) it had "a single root", "with many spikes, with infinite hair, intricate and of severe smell" ${ }^{57}$. The similarity of the rhizome of this plant to the trunk of the palm, which belongs to a particular type ${ }^{58}$, is very evident. Garcia de Orta states that Mateolo Senense had scolded Menardo and Fuchs "because they say that there is no true espique $e^{59,60}$. However, Fuchs had rightly pointed to the origin of 52"Diz q[ue] o xiferiix he tamarindo, e fenico balano he diuerso delle" (Orta, 1563: p. 202 verso; Orta, 1895: p. 323).

${ }^{53}$ In Laguna (1555: p. 96), we find the color “vayo”, “yellowish white”, but according to Alía Alberca (2010, pp. 104-105). Laguna's translation from the Greek original text is not correct and should rather be "a date of purple color", a color that effectively approximates reality.

${ }^{54}$ Chapter 1.109.1.1 - 1.109.3.9 in Wellmann's Greek edition reproduced and studied in Alía Alberca (2010, pp. 103-105).

55" Hic autem fructus a palmae Aegyptiae fructu ex osse differt: nam hic os habet magnum et longum et durissimum, in quo semen, uel ustum et tritum ualenter digerit, lib[ro] 6 comp[ositionis]

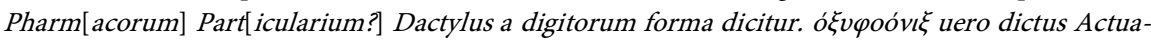
rio et aliis quibusdam Graecis recentioribus ab acido sapore, palmae syluestris fructus, Tamar Indus, id est, Dactylus indus Barbaris. Germanis uero Tamarinden." ("This fruit, however, differs from the Egyptian palm tree in that it has a not only large but also long and extremely hard stone; the seed is more easily digestible if heated and crushed. In the sixth book of De compositione medicamentorum secundum locos [of Galen], because it has the shape of the fingers, it is called Dactylus. However it

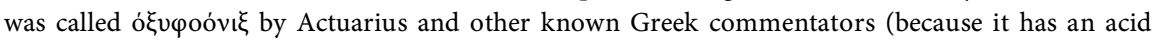
taste), and is the fruit of palma sylvestris, Tamar indus, that is, the wild date of India. The Germans, however, [call it] Tamarinden") (Cordus, 1549: p. 69).

${ }^{56}$ Bangladesh, China North-Central, China South-Central, East Himalaya, Myanmar, Nepal, Qinghai, Tibet, West Himalaya

(http://www.plantsoftheworldonline.org/taxon/urn:lsid:ipni.org:names:859418-1\#distribution-map). ${ }^{57}$ Chapter 1.7.1.1-1.7.3.1 in Wellmann's Greek edition reproduced and studied in Alía Alberca (2010: pp. 42-43).

${ }^{58}$ The trunk of the palm is cylindrical, unbranched and has a leaf crown on top.

${ }^{59}$ Portuguese designation for the palm tree trunk type.

60“Porq[ue] dizẽ[m] q[ue] nã[o] ha verdrdeiro espique" (Orta, 1563: p. 191 verso; Orta, 1895: p. 295). 
the word "spica" in the name of the plant, since although it was a root, its shape resembled a trunk of a palm ${ }^{61}$.

\section{The Ivory in Leonhart Fuchs According to Garcia de Orta. Ivory and the Elephant in Europe}

However, it is near the end of the work, in Colloquium 58 that we understand the thinking of the Portuguese doctor. Garcia de Orta's moral and religious "confession" follows a reference to ivory. According to Orta, Fuchs "a wise men, says that there is no true ivory in the world"62. This was not, in fact, what Fuchs actually wrote. His words must be analyzed in context, and the German master's description simply informed us that ivory was so sought after that it had become very expensive and difficult to obtain, giving way to the usual falsifications: "Ivory (elephant tusk) as is much sought after in so many circumstances, so has also become very expensive nowadays. So true ivory is almost impossible to find anywhere. In fact, what are usually for sale in the market instead, it seems, are sea fish teeth"63. Marginalia: There is no genuine ivory in the market" ${ }^{\prime 4}$.

Since the fifteenth century, the best quality ivory, obtained from the tusks of the African elephant (Loxodonta africana (Blumenbach, 1797) ${ }^{65}$, mainly from western equatorial Africa (Sierra Leone, Benin, Congo), arrived in Europe in pieces worked by African artisans (Fagg, 1959; Ross, 1992: pp. 32-35; Mark, 2007: pp. 189-211), or in its raw state. This trade acquired significant expression in the sixteenth century, and grew even further in the seventeenth, only to decline from the eighteenth century ${ }^{66}$, and the Portuguese initially played a significant role in $i^{67}$. A panoply of works of art, made in whole or in part with ivory, such as pestles, spoons, salt shakers, chests and desks (Trnek \& Vassallo e Silva, 2001: pp. 94-108, 194-202; Gschwend \& Lowe, 2017: pp. 116-122, 128-129, 134, 142, 166-167) were sold at very high prices on Rua Nova dos Mercadores in Lisbon (Gschwend \& Lowe, 2017: pp. 134, 142) and in other European cities. They have always been luxury objects, expensive and difficult to obtain, accessible on-

\footnotetext{
61"Nardus Indica quanquam radix est, tamen etiam Nardispica, a similitudine formae cum spica, uocatur." ("Nardus Indica, although it is a root, it is also called a Nardispica, given the similarity of its shape to that of a spike.") (Fuchs, 1550: pp. 263 verso-264 recto).

62“Lionardo fusio homẽ[m] doutor diz q[ue] não ha marfim verdadeiro no mundo" (Orta, 1563: p. 224 recto; Orta, 1895: p. 379).

${ }^{63}$ Fuchs may be referring to the narwhal tooth, an Arctic whale, or, more likely, the teeth of the sperm whale. The animal has 40 - 50 ivory teeth in the lower jaw.

${ }^{64 "}$ Ebur, elephantorum sunt dentes, quod ut alias summopere expetitum, ita nostra quoque aetate preciosissimum. Eo factum est ut nullibi pene uerum Ebur reperiatur. Quod enim uulgo huius uice in officinis prostat, marinorum piscium dentes esse uidetur. Marginalia: Ebur legitimum in officinis non prostat" (Fuchs, 1561: p. 61).

${ }^{65}$ The ivory from the tusks of the Indian elephant (Elephas maximus Linnaeus, 1758) is of much lower quality than its African counterpart and the females do not have them. An African elephant tusk weighs about 22.5 kilograms on average.

${ }^{66}$ In the nineteenth century, the very high prices fetched by ivory caused the large-scale slaughter of the African elephant, which led to a drastic decline in populations (Alpers, 1992).

${ }^{67}$ When the Portuguese arrived on the west coast of tropical Africa, elephant and ivory played important roles in local societies, particularly in Benin. In this country ivory and copper had more value than gold (Blackmun, 1992: p. 163).
} 
ly to some of the European elites; they were present in collections of the Portuguese and Spanish nobility, and in collections from European elites housed in the Habsburg Kunstkammer, such as those of Archduchess Margaret of Austria (1480-1530), Emperor Charles V (1500-1558) or Archduke Fernando II (1529-1595) (Trnek \& Vassallo e Silva, 2001: pp. 39-67, 94-95, 198-199). Raw ivory was also used in the making of religious pieces. European ivory art peaked in the late Gothic, 1475-1550. The Reformation would cause not only widespread destruction of the images and sculptures, but also a drastic reduction in orders for ivory religious pieces. Pieces for private use continued to be made, especially by artists with links to Italy, but on a much smaller scale (Yates, 1987: pp. 108-111).

Not only ivory but also the elephant itself was well known in Europe as a result of many drawings and written descriptions, particularly by Conrad Gesner (Gesner, 1551: pp. 409-442), and the presence of live animals that had been brought from India to Europe in considerable numbers after the opening of the maritime route to the East by the Portuguese (Lach, 1967). Between 1501 and 1514, Afonso de Albuquerque (1452-1515), governor of the Portuguese State of India, sent four young elephants from Cochin to Lisbon (Gschwend, 2010: p. 3). Possibly it was these pachyderms that the Flemish nobleman Jan Taccoen van Zillebeke observed when he landed in Lisbon on 11 April 1514. He only stayed in the capital for nine days, but was surprised and impressed to see "several times, three young [three-year-old] street elephants", accompanied by their keepers. The animals were found to be behaving in a manner that was "peaceful, doing no harm to anyone"; they "were peaceful by nature" as is usual with Asian elephants when they are domesticated and accompanied by their keepers. The Flemish traveler stated that with ivory "various jobs were being done", but these elephants were very young and had not yet grown their tusks (Stols et al., 2014).

During the 16th century, it is thought that a total of 13 Asian elephants were brought to Europe via Portugal. From Lisbon to their destination, elephants were spotted by Spaniards, Italians, Flemings and Germans during the stops they made along their route, particularly in cities such as Alicante, Genoa, Milan, Antwerp and Cologne. Where passed, they stimulated the curiosity of artists, naturalists, humanists and the ordinary people. With the benefit of direct observation, the naturalists were able to compare the descriptions of the ancient masters with actual evidence (Lach, 1967). In this context, it is important to mention several known cases: 1) The young white elephant Hanno that Afonso de Albuquerque had sent from Kochi to King Manuel I arrived in Lisbon in 1511. The Portuguese monarch later sent him as a gift to Pope Leo X. Hanno arrived in Rome in 1514 and was housed in the papal garden of the Belvedere Palace and later moved to a building in St. Peter's Square. He even participated in processions (Braga, 2015: p. 335) and was drawn by Rafael and Pietro Aretino before he died about two years later (Gschwend, 2010: pp. 4-5). 2) In 1549, the young ele- 
phant Solimão (or Solomon), born in 1540 in Ceylon, and brought to Lisbon in 1542, was offered by the Portuguese Queen Catherine of Austria to her grandson, Prince Charles of Spain (Lach, 1967: pp. 160-167). The elephant was then led to Aranda del Douro, near Burgos, where the prince lived. However, the high costs of upkeep of the animal would eventually lead to it travelling to Vienna (Austria), where it arrived in 1552 (and died the following year). In 1554, Emperor Maximilian had a medal engraved with a drawing of the animal by Michael Fuchs. During his long trip, and later in Vienna, the pachyderm attracted the attention of writers, painters and artists. While in Trent for three days, a wooden model of Solimão was erected. Bronze figurines of the animal were made in 1552 in northern Italy and Germany (Gschwend, 2010: pp. 23-24; Gschwend \& Lowe, 2017: pp. 199-200). There is also a drawing by an anonymous, possibly Flemish artist, of this elephant while in Vienna, which shows great realism and detail and could have been done for natural history studies (Gschwend, 2010: pp. 24-27). In 1560 Maximilian II commissioned a limestone bas-relief from Severin Brachmann, artist of his court in Vienna. Solomon was depicted behind the emperor, and in front of a camel, an animal that was often offered as a gift by Sultan Solomon of Constantinople to the Vienna court (Gschwend, 2010: pp. 31-32).

Now, an academic like Fuchs would hardly be unaware of this news to claim that there was no real ivory!

\section{Leonhart Fuchs, a "Heretic Condemned for Being a Lutheran" According to Garcia de Orta}

Garcia de Orta designates Fuchs's words as "such blatant lies that they do not even merit reprimand"68. But, after all, this statement is colored with the opinion that Fuchs's so-called problem was that he was a heretic condemned for being a Lutheran ${ }^{69}$. "In addition to his books being in the condemned [books] catalog", as Orta writes ${ }^{70}$, he was a recalcitrant Protestant. A friar of the Order of Preachers known to Orta that had practiced many times with him (Fuchs) had never been able to "convince" him, that is, to lead him to Roman Catholicism. Orta confesses that because Fuchs was Lutheran his works came to bore him. Fuchs had been "very shameless to say that there was no real ivory, there being so many elephants in all parts of India"71. Such was Garcia de Orta's interpretation that we have already shown to be incorrect. Garcia de Orta"s last sentence in this regard crystallizes what the Count Ficalho, responsible for the modern edition published in 1891-1895, very benignly described as "a certain religious intoler-

\footnotetext{
68“Ha hũas mentiras tã[o] grossas que não he bẽ $[\mathrm{m}]$ nẽ[m] mereçem ser reprendidas" (Orta, 1563: p. 224 recto; Orta, 1895: p. 379).

69“E ser hereie cõ[n]denado por luterano" (Orta, 1563: p. 224 recto; Orta, 1895: p. 379).

70"Porq[ue] alem d[e] hos seus liuros virem no cataloguo cõ[n]denados" (Orta, 1563: p. 224 recto; Orta, 1895: p. 379)

71 "Foi muyto desenuergonhado em dizer que não auia marfim verdadeiro auendo tantos allifantes em todallas bã[n]das da India”(Orta, 1563: p. 224 verso; Orta, 1895: p. 380).
} 
ance"72: "It seems that the Lutherans must have some ivory in hell that is kept for them" ${ }^{\text {"73 }}$. In this context it is important to discuss certain issues.

In fact, some works of these German academics ${ }^{74}$ appeared in the Catalogo dos livros que se prohibem (1581) ("Index of Forbidden Books"), but they were theological or doctrinal or, in scientific works, paragraphs or passages considered offensive to religion or morals, or even with divination, superstition or astrological prediction (Catalogo dos livros que se prohibem, 1581: pp. 3 verso - 4 recto, 6 verso, 7 recto, 27 verso). From Methodus seu ratio compendiaria (Fuchs, 1550, 1553), a medical (first part) and a materia medica work (second part), the extensive letter of dedication was to be deleted (Catalogo dos livros que se prohibem, 1581: p. 27 verso), as well as a paragraph from a given page ${ }^{75}$. In this paragraph, Fuchs rebelled against the "fasting and excessive use of fish and vegetables" practiced in the "spring season", contrary to what the "old doctors" advocated, and that these practices were the cause of "spreading so many fevers throughout the regions", especially since this season was "salubrious" according to Hippocrates. Fuchs was certainly referring to Easter, and to the restrictions that the Catholic Church imposed on its believers in this period. Now, the institutions that guarded the doctrine of Rome, namely the Inquisition, could not admit that these dietary restrictions were the cause of so many diseases! From Fuchs's De sanandis totius humani corporis malis the letter of dedication and the foreword was to be prohibited ${ }^{76}$ (Catalogo dos livros que se prohibem, 1581: p. 28 recto).

Finally, on the subject of Orta's religious ideas, various opinions have been expressed, sometimes identifying him as a practitioner of Judaism or Crypto-Judaism, sometimes as a Catholic (Silva Carvalho, 1934; Friedenwald, 1941; Martins, 1963; Silva Rego, 1963; Pearson, 2001, Pimentel \& Soler, 2014). His comments on Leonhart Fuchs we have just discussed do not permit clarification of this issue, but merely serve to contribute to its discussion. It was precisely the ${ }^{72}$ Silva Rego (1963) interpreted this passage from the Coloquios as one of the strongest arguments in favor of Orta's Catholic belief.

73"Pareçe que os luteranos deuẽ $[\mathrm{m}]$ ter no inferno algũ $[\mathrm{m}]$ marfim q[ue] seia guardado para elles" (Orta, 1563: p. 224 verso; Orta, 1895: p. 380).

${ }^{74}$ From Otho Brunfels, a large number of theological and doctrinal works (De Bujanda et al., 1995: p. 718) and John Huss (1369-1415)' works published in 1524-1525 by Brunfels (De Bujanda et al., 1995: p. 249).

75" Quare contra ueterum medicorum praescriptum faciunt, qui uerno tempore humana corpora ieiuniis et immodico piscium ac leguminum usu temere affligunt. Neque enim citra insigne bonae ualetudinis, atque adeo uitae dispendium, iis obsequi licet. Quanto autem periculo illis sit obtemperatum, uel hinc facile coniicere licebit, quod uix ullo alio tempore perinde atque uerno (quod tamen Hippocratis etiam testimonio saluberrimum est, et minime exitialibus morbis obnoxium) febres magis per omnes regiones grassatae fuerint." ("How do they act against the prescription of the old doctors, who in the spring season, for no reason, weaken human bodies with fasting and excessive use of fish and vegetables! They should not even be allowed to fall short of the mark of good health, let alone the loss of life. How much danger, moreover, is to them what is not disputed, or what can easily be called into question now, for hardly in any other season, in the degree of spring (which, however, in the testimony of Hippocrates, is salubrious, and very little susceptible to fatal diseases) so many fevers will have spread throughout") (Fuchs, 1553: p. 34 verso).

${ }^{76}$ The editions that we found (Fuchs, 1543, 1546, 1547) feature the dedicatory letter, but do not feature the proem. 
attacks launched against L. Fuchs that form one of the arguments put forward to conclude Orta's connection with Catholicism ${ }^{77}$, knowing that the Catholic Church then harbored special hatred towards Protestants ${ }^{78}$. On the other hand, the acutely violent, theologically based attacks launched by Martin Luther against Judaism (Probst, 2005; Carty, 2019), crystallized in the work Von den Jüden und iren Lügen (On Jews and Their Lies), published in 1543, advocating that the princes of the empire should burn synagogues and schools, raze all Jewish homes, destroy all Jewish books, forbid Rabbis to teach, abolish any provisions for safe passage, and confiscate all currency and property in Jewish possession (Carty, 2019: p. 323), may have triggered reactions from Jewish scholars (see Ariel, 2010), and it would be in this context that Orta's words against Fuchs could be framed. There is yet another interpretation: Garcia de Orta launched the violent attack on L. Fuchs to try to hide his connection with Judaism from the Inquisition, presenting himself as ultra anti-protestant and therefore a fervent Catholic. If this was his goal, it had no effect at all, as his bones would be burned at the stake!

What happened after the death of Garcia de Orta? The Inquisitor Aleixo Dias Falcão had Orta's sister Catarina arrested in October 1568. In her testimonies, she accused his brother of Judaizing practices, but dismissed herself several times and was eventually convicted in October of the following year. The Inquisitor left office in 1572. The new Inquisitor, Bartolomeu da Fonseca, filed a lawsuit, where Garcia de Orta was judged to be a practicing Jew. The deed of faith was performed on December 4, 1580, and his bones were thrown into the fire twelve years after his death (Liberato, 2011). Silva Carvalho (1934) argued for an Orta link to the Hebrew faith. However, the conclusion is based on an analysis of the biography of the Orta's family members, especially the Inquisition proceedings brought against several members of Orta's family. Although the amount of information presented is comprehensive and exhaustive, Silva Carvalho's path of reasoning can be questioned for two reasons that we consider fundamental: 1) Even though several (or all) members of the Orta family profess the Jewish faith, this does not necessarily imply that Garcia de Orta was a Jew. 2) In view of the operating methods of the Portuguese Inquisition, in particular as regards the conduct of the proceedings, using the most violent methods of torture, serious

\footnotetext{
${ }^{77}$ See the argument put forward by Silva Rego (1963) and Martins (1963).

${ }^{78}$ The ideology of Anti Semitism began to emerge in the 2nd century, when Christian theologians first foretold that the Antichrist would be a Jew from the tribe of Dan. Satan was given Jewish features; it was believed Jews held secret tournaments as soldiers of the Antichrist, during which they committed ritual murders. Jews were seen as murderers of Christ and murderers continually to the present through their denial of his divinity. The Jewish condition deteriorated in Europe from the Second Crusade, in the 12th century. Discriminatory measures were taken, and synagogues were destroyed or confiscated. At the Lateran Council in 1215 Jews were barred from owning land and all military and civil functions. Then came the expulsions: from England in 1290, from France in 1394, from different cities in Germany from the 13th to the15th century, from Spain in 1492, from Portugal in 1497, and from the Kingdom of Naples in 1541. Established in the Iberian Peninsula in the 16th century, the Inquisition was mainly directed against Jews and, to a lesser extent, against Protestants (Johnson, 1976: pp. 245-246, 297-298, 306-308; Delumeau \& Melchior-Bonnet, 1997: pp. 137, 157-160).
} 
doubts may be raised as to the truth of the statements made by the accused. Révah (1960) proceeded to an analysis of the inquisitorial processes of the Orta family members, and concluded that the Portuguese doctor engaged in the practice of Crypto-Judaism.

In the very first Colloquium of his work, Garcia de Orta wrote emphatically: "In all things I will serve you and tell you the truth"79. A little later in this brief colloquy, Orta promised to declare what he did not know: "I promise to serve you and say the little I know, and soon I will tell you the things I know well and the things I doubt, with an oath to speak much truth." ${ }^{\text {. }}$. Jean Delumeau characterized the Renaissance as "an ocean of contradictions, a sometimes discordant concert of divergent aspirations, an uneasy cohabitation of the will for power and a science still in its infancy, the desire for beauty and an unhealthy appetite for the horrible, a mixture of simplicity and complications, purity and sensuality, charity and hatred" (Delumeau, 1984: p. 10). Garcia de Orta, an assumed man of the Renaissance, went beyond the primary object of his work which was the dissemination of the natural history of India. Whatever his ultimate motive was, he embarked on religious and confessional issues and misrepresented, perhaps deliberately, the words of Lutheran academics, thus becoming, as did many other intellectuals of this period, part of the "ocean of contradictions" of which Jean Delumeau writes.

\section{Conclusion}

1) In their botanical works, Valerius Cordus and Leonhart Fuchs provided elements that enriched Dioscorides's De materia medica.

2) Garcia de Orta profited from using the works of Valerius Cordus on cardamom, cassia lignea, cinnamon, lignum aloes and tamarind fruit.

3) However, Garcia de Orta's attitude towards Fuchs was harsh, as he distorted what Fuchs actually wrote about ivory merely because he was, in Orta's words, a "heretic condemned for being a Lutheran".

4) Orta's Renaissance humanism, crystallized in his very first Colloquium where he stated that he would tell the whole truth and declare what he did not know, could not withstand the influence of his religious beliefs. Orta did not escape the profound doctrinal and theological division that then raged in Europe after the emergence of the reform movement.

\section{Conflicts of Interest}

The author declares no conflicts of interest regarding the publication of this paper.

\section{References}

Alía Alberca, M. L. (2010). ¿La "Materia médica” de Dioscórides traducida por Laguna?

\footnotetext{
79 "E porque todas estas cousas ham de ser ditas na verdade" (Orta, 1563: p. 1 verso; Orta, 1891: p. 19).

80“'Prometo de vos seruir e dizer ho pouquo q[ue] souber, e logo vos ey de dizer as cousas que sey bẽ[m] sabidas (Orta, 1563: p. 1 verso; Orta, 1891: p. 20).
} 
Aportaciones de las nuevas teorías traductológicas. Tesis Doctoral, Madrid: Universidad Complutense de Madrid, Facultad de Filología.

Alpers, E. A. (1992). The Ivory Trade in Africa. An Historical Perspective. In D. H. Ross (Ed.), Elephant: The Animal and Its Ivory in African Culture (pp. 349-386). Los Angeles: Fowler Museum of Cultural History, University of California.

Ariel, Y. (2010). The One and the Many: Unity and Diversity in Protestant Attitudes toward the Jews. The Protestant-Jewish Conundrum, Studies in Contemporary Jewry, 24, 15-45.

Bethencourt, F. (1994). Historia das Inquisições. Portugal, Espanha e Itália. Lisboa: Círculo de Leitores.

Blackmun, B. W. (1992). The Elephant and Its Ivory in Benin. In D. H. Ross (Ed.), Elephant: The Animal and Its Ivory in African Culture (pp. 163-186). Los Angeles: Fowler Museum of Cultural History, University of California.

Braga, I. D. (2015). Descobrir e juntar animais: "Novas Novidades", Pátio dos Bichos e Jardim Zoológico de Lisboa. In I. D. Braga, \& P. D. Braga (Eds.), Animais e Companhia na Historia de Portugal (pp. 317-389). Lisboa: Círculo de Leitores.

Brendle, F. (2001). Universität Tübingen. In Lexikon für Theologie und Kirche, Zehnter Band (pp. 286-288). Thomaschristen bis Zytomyr. Freiburg: Herder.

Cabral, J. P. S. (2015). Tradição e inovação na botânica dos Colóquios. Os cocos e as palmeiras segundo Garcia de Orta. In A. Cardoso, \& P. F. da Costa (Eds.), Botânica, Medicina e Cultura nos "Colóquios" de Garcia de Orta (pp. 85-112). Lisboa: Colibri.

Cadafaz de Matos, M. (2001). Erasmo e os índices inquisitoriais portugueses no século XVI. In A. Polónia, J. M. Ribeiro, \& L. A. Oliveira Ramos (Eds.), Estudos em homenagem a João Francisco Matos (pp. 131-146). Porto: Faculdade de Letras da Universidade do Porto.

Carty, J. A. (2019). Martin Luther's Anti-Judaism and Its Political Significance. Antisemitism Studies, 3, 317-342. https://doi.org/10.2979/antistud.3.2.06

Catalogo dos livros que se prohibem nestes Regnos \& Senhorios de Portugal. (1581). Impresso em Lisboa per Antonio Ribeiro.

Cohen, H. F. (2010). How Modern Science Came into the World. Four Civilizations, One 17th-Century Breakthrough. Amsterdam: Amsterdam University Press, 99-156.

Cordus, V. (1549). Pedanii Dioscoridis Anazarbei, De Medicinali Materia libri sex. France: Apud Chr. Egenolphum.

Cordus, V. (1561). Annotationes in Pedacii Dioscoridis Anazarbei Medica materia libros. Argentorati: Excudebat Iosias Rihelius.

D’Cruz, I. A. (1991). Garcia Da Orta in Goa: Pioneering Tropical Medicine. British Medical Journal, 303, 1593-1594. https://doi.org/10.1136/bmj.303.6817.1593

D'Esaguy, A. (1937). Garçia Dorta and the Inquisition. Bulletin of the Institute of the History of Medicine, 5(5), 483-487.

De Bujanda, J. M., Daignon, R., Richter, M., \& Stanek, E. (1995). Index de I'Inquisition Portugaise, 1547, 1551, 1561, 1564, 1581. Collection Index des livres interdits. Volume IV. Éditions de l'Université de Sherbrooke, Centre d'Etudes de la Renaissance, Librairie Droz.

Delumeau, J. (1984). La Civilisation de la Renaissance. Paris: Arthaud.

Delumeau, J., \& Melchior-Bonnet, S. (1997). Des religions et des hommes. Paris: Desclée de Brouwer.

Dias, J. L. (1964). O Renascimento em Amato Lusitano e Garcia d'Orta. Estudos de Cas- 
telo Branco: Revista de História e Cultura, 11, 5-34.

Egerton, F. N. (2003). Botany during the Italian Renaissance and Beginnings of the Scientific Revolution. Bulletin of the Ecological Society of America, 84, 130-137. https://doi.org/10.1890/0012-9623(2003)84[130:AHOTES]2.0.CO;2

Elliott, B. (2011). The World of the Renaissance Herbal. Renaissance Studies, 25, 24-41. https://doi.org/10.1111/j.1477-4658.2010.00706.x

Engler, A. (1875). Bock, Hieronymus. In Allgemeine Deutsche Biographie (Vol. 2, p. 766). München/Leipzig: Duncker \& Humblot.

Fagg, W. B. (1959). Afro-portuguese ivories. London: Batchworth Press.

Feger, O. (1955). Blarer, Ambros. In Neue Deutsche Biographie (Vol. 2, p. 287-288). Berlin: Duncker \& Humblot.

Ficalho, C. D. (1886). Garcia da Orta e o seu tempo. Lisboa: Imprensa Nacional. https://doi.org/10.5962/bhl.title.24354

Friedenwald, H. (1937). Amatus Lusitanus. Bulletin of the Institute of the History of Medicine, 5, 603-653.

Friedenwald, H. (1941). The medical pioneers in the East Indies. Bulletin of the History of Medicine, 9, 487-504.

Fuchs, L. (1543). De sanandis totius humani corporis eiusdemque partium tam internis quam externis malis libri quinque. Parisiis: Apud Iacobum Bogardum.

Fuchs, L. (1546). De sanandis totius humani corporis eiusdemque partium tam internis quam externis malis libri $V$. Lugduni: Apud Guillelmum Rovilium.

Fuchs, L. (1547). De sanandis totius humani corporis malis libri quinque. Lugduni: Apud Ioannem Frellonium.

Fuchs, L. (1550). Methodus seu ratio compendiaria cognoscendi veram solidamque medicinam. Parisii.

Fuchs, L. (1553). Methodus seu ratio compendiaria perveniendi ad veram. Parisiis.

Fuchs, L. (1561). Operum Leonharti Fuchsii, Tomus Primus. Francofurti ad Moenum.

Gelásio Dalgado, D. (1894). Classificação botanica das plantas e drogas descriptas nos 'Coloquios da Índia' de Garcia d'Orta. Bombain: Nicol's Printing Press.

Gelásio Dalgado, D. (1898). Flora de Goa e Savantvadi. Lisboa: Imprensa Nacional.

Gesner, C. (1551). Historiae Animalium lib. I de Quadrupedibus viviparis. Tiguri Apud Christ. Froschoverum.

Grimm, H. (1955). Brunfels, Otto. In Neue Deutsche Biographie (Vol. 2, p. 677). Berlin: Duncker \& Humblot.

Grove, R. (1996). Indigenous Knowledge and the Significance of South-West India for Portuguese and Dutch Constructions of Tropical Nature. Modern Asian Studies, 30, 121-143. https://doi.org/10.1017/S0026749X00014104

Gschwend, A. J. (2010). The story of Süleyman: Celebrity Elephants and Other Exotica in Renaissance Portugal. Philadelphia: Pa Pachyderm.

Gschwend, A. J., \& Lowe, K. J. P. (2017). A cidade global. Lisboa no Renascimento, Lisboa: Imprensa Nacional-Casa da Moeda.

Husemann, T. (1876). Cordus, Valerius. In Allgemeine Deutsche Biographie (Vol. 4, pp. 479-480). München/Leipzig: Duncker \& Humblot.

Johnson, P. (1976). A History of Christianity. Harmondsworth: Pelican Books.

Kapil, R. N., \& Bhatnagar, A. K. (1976). Portuguese Contributions to Indian Botany. Isis, 67, 449-452. https://doi.org/10.1086/351635 
Lach, D. F. (1967). Asian elephants in Renaissance Europe. Journal of Asian History, 1, 133-176.

Laguna, A. (1555). Pedacio Dioscorides Anazarbeo, Acerca de la materia medicinal, y de los venenos mortiferos. Traduzido de la lengua Griega, en la vulgar Castellana, \& illustrado con claras y substantiales Annotationes, y con las figuras de innumeras plantas exquisitas y raras, por el Doctor Andres Laguna, Medico de Iulio III. Pont. Max. Anvers: En casa de Iuan Latio.

Liberato, M. C. (2011). Contribuição para o conhecimento de Garcia de Orta. Revista de Ciências Agrárias, 34, 110-119.

Mark, P. (2007). Towards a Reassessment of the Dating and the Geographical Origins of the Luso-African Ivories, Fifteenth to Seventeenth Centuries. History in Africa, 34, 189-211. https://doi.org/10.1353/hia.2007.0012

Martins, A. (1963). O catolicismo de Garcia de Orta. Broteria, 77, 35-46.

Mathew, K. S. (1997). The Portuguese and the study of medicinal plants in India in the sixteenth century. Indian Journal of History of Science, 32, 369-376.

Ogilvie, B. W. (2003). The Many Books of Nature: Renaissance Naturalists and Information Overload. Journal of the History of Ideas, 64, 29-40. https://doi.org/10.1353/jhi.2003.0015

Orta, Garcia de. (1563). Coloquios dos simples, e drogas he cousas mediçinais da India, e assi dalgũas frutas achadas nella onde se tratam algũas cousas tocantes a mediçina, pratica, e outras cousas boas, pera saber cópostos pello Doutor garçia dorta. Goa: Ioannes de endem.

Orta, Garcia de. (1891). Coloquios dos Simples e Drogas da India. Volume I. Edition and commentaries by Count Ficalho. Lisboa: Imprensa Nacional.

https://doi.org/10.5962/bhl.title.104993

Orta, Garcia de. (1895). Coloquios dos Simples e Drogas da India. Volume II. Edition and commentaries by Count Ficalho. Lisboa: Imprensa Nacional.

Paiva, J. (2018). Introdução aos Colóquios dos Simples de Garcia de Orta. Obras Pioneiras da Cultura Portuguesa, volume 15, Primeiro livro de botânica. Lisboa: Círculo de Leitores.

Pearson, M. N. (2001). Hindu Medical Practice in Sixteenth-Century Western India: Evidence from Portuguese Sources. Portuguese Studies, 17, 100-113.

Pimentel, J., \& Soler, I. (2014). Painting Naked Truth: The Colóquios of Garcia da Orta (1563). Journal of Early Modern History, 18, 101-120. https://doi.org/10.1163/15700658-12342386

Pires, M. J. P. (1984). Aspectos históricos dos recursos genéticos de plantas medicinais. Rodriguésia, 36, 61-66. https://doi.org/10.1590/2175-78601984365906

Probst, C. (2005). Martin Luther and The Jews. A Reappraisal. The Theologian, The Internet Journal of Integrated Theology. http://www.theologian.org.uk/churchhistory/lutherandthejews.html

Quattrocchi, U. (2016). CRC World Dictionary of Medicinal and Poisonous Plants: Common Names, Scientific Names, Eponyms, Synonyms, and Etymology (5 Volume Set). Boca Raton, Fla: CRC Press. https://doi.org/10.1201/b16504

Rath, G. (1961). Fuchs, Leonhart. In Neue Deutsche Biographie (Vol. 5, S. 681). Berlin: Duncker \& Humblot.

Révah, I. S. (1960). La famille de Garcia de Orta. Revista da Universidade de Coimbra, 19, 407-420.

Ricardo Jorge (1962). Amato Lusitano. Comentos à sua vida, obra e época. Lisboa: Insti- 
tuto de Alta Cultura.

Rodolfo Dalgado, S. (1982). Glossário Luso-Asiatico. Volume I. A-L. Hamburg: Helmut Buske Verlag.

Ross, D. H. (1992). Imagining elephants. An overview. In D. H. Ross (Ed.), Elephant. The Animal and Its Ivory in African Culture (pp. 1-41). Los Angeles: Fowler Museum of Cultural History, University of California.

Saraiva, A. J. (1969). Inquisição e cristãos-novos (4th Edition). Porto: Editorial Inova.

Schmitz, R. (1981). Cordus, Valerius. In C. C. Gillispie (Ed.), Dictionary of Scientific Biography (Vol. 3, pp. 413-415). New York: Charles Scribner's Sons.

Schoff, W. H. (1912). Introduction. The Periplus of the Erythraean Sea. Translated from the Greek and Annotated by Wilfred H. Schoff. New York: Longman.

Schütz, A. (2009). Die Wahrheit entdecken. Garcia da Orta und die ,Gespräche über die einfachen Heilmittel' (Goa 1563). Sudhoffs Archiv, 93, 26-66.

Silva Carvalho, A. D. (1934). Garcia d'Orta. Revista da Universidade de Coimbra, 12, 61-246.

Silva Rego, A. D. (1963). Garcia de Orta e a ideia de tolerância religiosa. Garcia de Orta, 11, 663-676.

Singer, C. (1927). The Herbal in Antiquity and Its Transmission to Later Ages. The Journal of Hellenic Studies, 47, 1-52. https://doi.org/10.2307/625251

Stannard, J. (1969). The Herbal as a Medical Document. Bulletin of the History of Medicine, 43, 212-220.

Stannard, J. (1970a). Bock, Jerome. In C. C. Gillispie (Ed.), Dictionary of Scientific Biography (Vol. 2, pp. 218-220). New York: Charles Scribner's Sons.

Stannard, J. (1970b). Brunfels, Otto. In C. C. Gillispie (Ed.), Dictionary of Scientific Biography (Vol. 2, pp. 218-220). New York: Charles Scribner's Sons.

Stauffer, R. (1970). A Reforma (1517-1564). Lisboa: Livros do Brasil.

Stols, E., Fonseca, J., Manhaeghe, S., \& van Zillebeke, J. T. (2014). Lisboa em 1514. O relato de Jan Taccoen van Zillebeke. Lisboa: Edições Húmus.

Thomaz, L. F. (1995). Especiarias do Velho e do Novo Mundo (notas histórico-filológicas). Arquivos do Centro Cultural Calouste Gulbenkian (Paris), 34, 219-345.

Thorley, J. (1969). The Development of Trade between the Roman Empire and the East under Augustus. Greece \& Rome, Second Series, 16, 209-223. https://doi.org/10.1017/S001738350001706X

Touwaide, A. (2003). Nature's Medicine Cabinet: Notes on Botanical Therapeutics at the Birth of the New World. Journal of the Washington Academy of Sciences, 89, 141-150.

Touwaide, A. (2008). Botany and humanism in the Renaissance: background, interaction, contradictions. Studies in the History of Art, 69, Symposium Papers XLVI: The Art of Natural History: Illustrated Treatises and Botanical Paintings, 1400-1850, 32-61.

Trnek, H., \& Vassallo e Silva, N. (2001). Exotica. Os Descobrimentos portugueses e as Câmaras de Maravilhas do Renascimento. Lisboa: Fundação Calouste Gulbenkian.

Winius, G. D. (1998). The Renaissance as reflected in Goa. Mediterranean Studies, 7, 125-134.

Yates, S. (1987). Europe. Sixteenth, Seventeenth and Eighteenth Centuries. In Fiona St Aubyn (Ed.), Ivory. An International History and Illustrated Survey (pp. 108-130). New York: Harry N. Abrams. 